\title{
Pumped Storage Hydropower Plants Environmental Impacts using Geomatics Techniques: An Overview
}

\author{
A. D. Prasad, Kamal Jain and Ajay Gairola \\ Department of Civil Engineering \\ Indian Institute of Technology Roorkee \\ Roorkee, India
}

\begin{abstract}
The Pumped Storage Hydropower plants are generally developed to improve the peak power scenario of any country in the world and also in India. These types of projects involve construction of upper, lower reservoirs and the supporting infrastructure includes cement concrete mixing plant, quarters for working staff, service roads and disposal ground, which in turn demanded a huge amount of forest and agricultural land. In this paper an attempt has been made to give an overview of Pumped Storage Hydropower plants environmental impacts using geomatics techniques. Landsat data and Advanced Spaceborne Thermal Emission and Reflection Radiometer's (ASTER) Global Digital Elevation Model (GDEM) of $30 \mathrm{~m}$ resolution data have been used for processing, interpretation and analysis of various parameters.
\end{abstract}

The overall environmental Impacts of pumped storage hydropower plants depending on the selection of site, shape and size of reservoir, operational regime, mitigating measures, can be limited, but must be evaluated case by case with detailed surveys including social and political aspects.

\section{General Terms}

GIS, Environmental Impacts.

\section{Keywords}

Renewable Energy; Pumped Storage Hydropower; Geomatics Techniques.

\section{INTRODUCTION}

An assessment of the possible positive, negative impacts that a proposed project may have on environment before and after execution is called as Environmental Impact Assessment (EIA). The assessment consists of the environmental, social and economical aspects. The parameters to be considered are of environmental receptors like air quality, water quality, noise, land use change, levels of local unemployment and crime etc.

Ministry of Environment and Forest (MoEF) is responsible for environmentally compatible and sustainable development of India. A notification has been issued by the MoEF on 27th January 1994, making EIA mandatory for 30 categories of developmental projects among which hydropower is a significant one. The main objective of EIA is to influence the decision-making procedure of the project development by providing sound information on environmental impacts and the means for preventing or reducing those impacts.

\section{HYDROPOWER}

Hydropower is the only renewable energy technology which is presently commercially practicable on a large scale. The major advantages of hydropower are renewable, production of greenhouse gases is negligible, the least costly way of storing huge amount of electricity and have firm control of electricity production based on demand. Hydropower accounts for about
$17 \%$ of global generating capacity, and about $20 \%$ of the energy produced each year (1).

Hydropower plant uses a dam of convincing height at a location to store river water in a reservoir in the form of potential energy. When water released from the reservoir, the stored potential energy converted to kinetic energy flows through a turbine and used to spinning it, which in turn activates a generator to produce electricity [Figure.1].

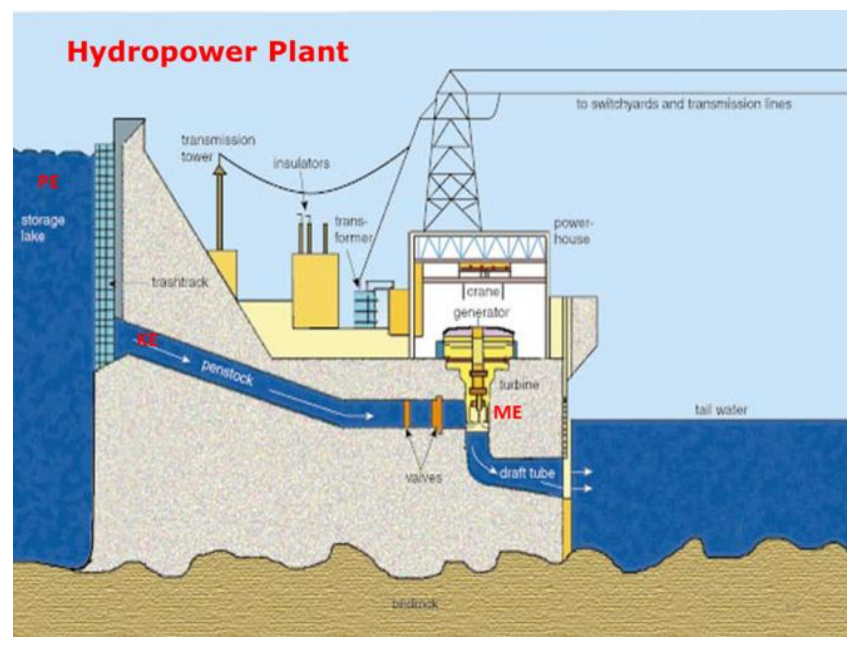

Figure.1 Hydropower Plant

\section{PUMPED STORAGE HYDROPOWER}

Since 1890, Pumped Storage Hydropower is the most established technology for utility-scale electricity storage and has been commercially deployed. However, worldwide there have been revived interest in developing the technology. Most of the low-carbon emission electricity resources like wind, solar, and nuclear energy plants cannot adapt their output to match inconsistent power demands were as Pumped Storage Hydropower plants have flexibility to adapt output with demand. To mitigate global warming, there is an increasing need for bulk electricity storage.

Pumped Storage Hydropower plant stores energy by pumping water from a lower reservoir to an upper reservoir during off peak periods. During peak periods, water is released back to the lower reservoir to generate electricity (4) [Figure.2]. 


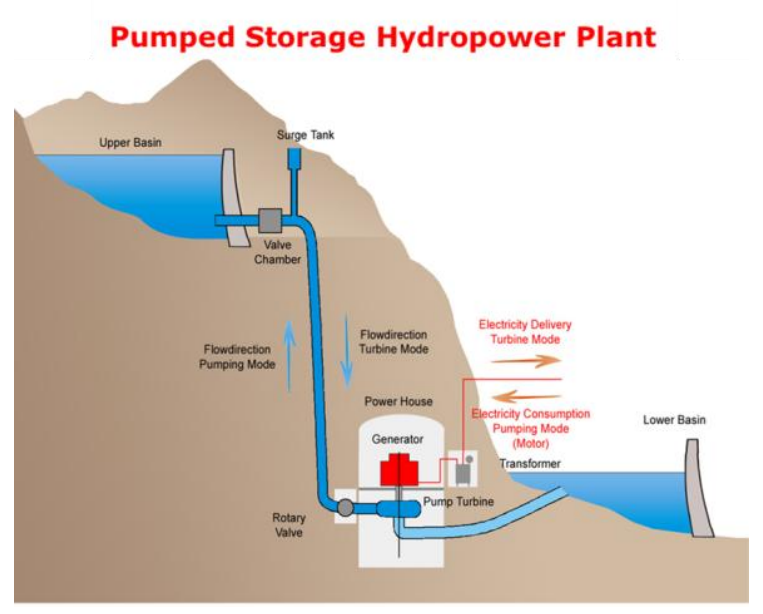

Figure.2 Pumped Storage Hydropower Plant

\section{ENVIRONMENTAL AND SOCIAL ISSUES}

Environmental and social impacts have been the subject of enthusiastic ponders for hydropower projects. Communication of objective information to the public is essential and a need for countries to can make good decisions with respect to hydropower projects. The environmental agencies will provide such information on possible social and environmental impacts and also on mitigation measures of those impacts.

\subsection{Environmental Analysis Comparisoin for Options}

There is a serious need to compare the relative environmental costs and benefits of the various sources of power generation. Undeniably, electricity demand continues to increase worldwide and hence there is a significant ecological and social impact throughout the world. Most of the environmental and social impacts caused around the world and countries having highly population like India are due to human activity or actions and power generation projects are no exception. Electricity can be created from a range of primary energy sources and conversion technologies like other economic activities. The life-cycle of the production process must be considered when comparing the environmental impacts of electricity options.

\subsection{Environmental Analysis Comparisoin based on Life-cycle Analysis of Hydropower} The comparison of the relative environmental performance of power generation systems on the basis of life-cycle analysis (LCA) does not eliminate the need for value judgements and arbitration. This is due to the fact that many impacts are impossible to compare directly (e.g., local land use issues for hydropower versus the management of radioactive wastes for nuclear power, or versus the management of global and regional atmospheric issues for coal, oil and natural gas based power). Another constraint of life-cycle analysis is that it cannot easily account for "non-quantifiable" or "qualitative" impacts, such as landscape, social, or biodiversity issues. However, despite this "structural" negative bias, hydropower still comes out ahead of other electricity systems in most lifecycle comparisons. Synthesis of Environmental Parameters for Electricity Options is provided in Table.1.

\section{ENVIRONMENTAL IMAPACT OF HYDROPOWER}

When compared all major power generation options, hydropower is the source of both significant and unavoidable environmental and social impacts. Unavoidable impacts of hydropower projects are generally related to the flooding of land in the impoundment zone upstream of a dam and to changes to water flows and water levels downstream of a dam. Such impacts are site specific and tend to vary in scale according to the size of the project [Figure.3].

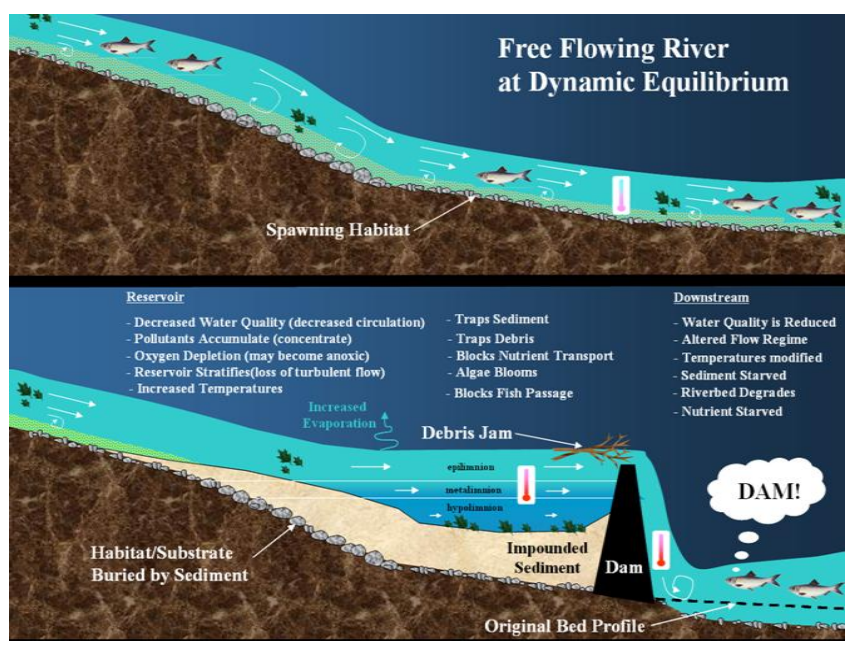

Figure.3 Environmental Impact of Hydropower Plant

The main challenges remain to be addressed are briefly as below (5).

- Issues related to the conservation of rare or protected species and maintaining aquatic varieties.

- Issues related to when communities rely on subsistence fishing or seasonal flooding of fields downstream of a reservoir.

- Improving fish passages for migratory species in turbine, spillway, and overflow at hydropower dam sites.

- Sedimentation management in reservoirs.

- Water quality, eutrophication and water contamination issues due to untreated domestic sewage and runoff from agricultural or industrial uses.

\section{SOCIOECONOMIC IMPACTS OF HYDROPOWER}

The major challenges associated with hydropower projects particularly in India and other highly populous countries. Projects got delayed, abandoned because of socioeconomic concerns, such as:

- Displacement and loss of source of revenue for populations living in/downstream of the lock away zone

- Loss of resources to support traditional ways of life

- Prevalence of diseases among susceptible communities

- Scant relocation of project reimbursements to affected people.

Table. 2 provides Comparison of GIS-generated estimates from the study with numbers of affected people documented in the literature and Figure.4 Illustrates the method used to estimate the size of downstream populations (6). 
Table. 3 provides estimated numbers of potentially affected people, classified by severity of river impact. As illustrated by Table. 3 and Figure.5, the potentially affected populations are heavily concentrated in Southeast Asia and India, where together more than half of all large dams have been built in the world's most populous region.

\section{METHODOLOGY AND RESULTS}

Landsat data and Advanced Spaceborne Thermal Emission and Reflection Radiometer (ASTER) Global Digital Elevation Model (GDEM) of $30 \mathrm{~m}$ resolution data have been used for processing, interpretation and analysis of various parameters. Various methodologies (1, 2, 3, and 4) have been followed for parameter analysis and the results of the study area [Figure.6] are presented in Figure.7, 8 \& 9 respectively.

\section{CONCLUSION}

The overall environmental Impacts of pumped storage hydropower plants depending on the selection of site, shape and size of reservoir, operational regime, mitigating measures, can be limited, but must be evaluated case by case with detailed surveys including social and political aspects.

Notes for less Environmental and Social Impact during various phases:

\section{A. Site Selection}

- Maximum head between lower and upper reservoirs and contain large volume

- Reservoirs with steep sides to reduce loss of littoral zone and with low erosion risk

- $\quad$ Avoid spreading of invasive species

B. Avoid Extereme Operational Regimes

- Analyse and find biological threshold values

- Biology seasonality should be considered

C. Site Specific Investigations

- Detailed physical studies to be done for all environmental and socioeconomical parameters

\section{REFERENCES}

[1] A D Prasad, Kamal Jain, Ajay Gairola, R HernandezGuzman, Ranking of Pumped Storage Hydropower Site for Preliminary Studies, International Journal of Earth Sciences and Engineering 01/2013; 06(01):136-142.

[2] A D Prasad, Kamal Jain, Ajay Gairola, Mapping of Lineaments and Knowledge Base Preparation using Geomatics Techniques for part of the Godavari and Tapi Basins, India: A Case Study, International Journal of Computer Applications Volume 70- No.9, May 2013

[3] A D Prasad, Kamal Jain, Ajay Gairola, Surface Temperature Estimation using Landsat Data for part of the Godavari and Tapi Basins, India: A Case Study, IJEAT, Volume-2, Issue-3, February 2013

[4] A D Prasad, Kamal Jain, Ajay Gairola, Knowledge Based Pumped Storage Hydro Potential Site Selection Using Geomatics Techniques, - Under Review

[5] IEA. Hydropower and the Environment: Present Context and Guidelines for Future Action. Vol. II: Main Report, Ch.3: "Comparative Environmental Analysis of Power Generation Options. May 2000

[6] Richter, B.D.; Postel, S.; Revenga, C.; Scudder, T.; Lehner, B.; Churchill, A. and Chow, M. Lost in development's shadow: The downstream human consequences of dams. Water Alternatives 2010: 3(2): $14-42$.

\section{AUTHOR'S PROFILE}

A. D. Prasad received B. Tech from Andhra University, M. Tech. from National Institute of Technology Karnataka. He worked as Asst. Environmental Engineer in the initial days of the career and afterwards shifted to IT sector, worked in the domain SAP - BI / SEM / IP and performed various roles as team member, technical leader, lead consultant, project manager and competency head. $\mathrm{He}$ worked at various capacities in India, USA, UAE, Saudi Arabia, Qatar, Malaysia, UK and South Africa before joining as a research scholar at Indian Institute of Technology Roorkee, India. He is also delivering lectures at various universities. His research interests include Energy, Renewable Energy, GIS, HAZOP, Hazards and Mitigation, Impact Analysis, SAP-GIS and Medical Image Processing. He is a life member of IGS (India). 
Table.1: Synthesis of Environmental Parameters for Electricity Options

\begin{tabular}{|c|c|c|c|c|c|c|c|c|}
\hline $\begin{array}{l}\text { Electricity } \\
\text { Generation } \\
\text { Options } \\
\text { (classified } \\
\text { by level of } \\
\text { service) }\end{array}$ & $\begin{array}{c}\text { Energy } \\
\text { Payback } \\
\text { Ratio }\end{array}$ & $\begin{array}{l}\text { Greenhouse } \\
\text { Gas Emissions } \\
\text { (kt eq.CO2/TWh) }\end{array}$ & $\begin{array}{c}\text { Land } \\
\text { Requirements } \\
\left(\mathrm{km}^{2} / \mathrm{TWh} / \mathrm{y}\right)\end{array}$ & $\begin{array}{c}\mathrm{SO} 2 \\
\text { Emissions } \\
\text { (t SO} 2 / \mathrm{TWh})\end{array}$ & $\begin{array}{c}\mathrm{NOx} \\
\text { Emissions } \\
\text { (t NO } / \mathrm{TWh})\end{array}$ & $\begin{array}{l}\text { NMVOC } \\
\text { Emissions } \\
\text { (t/TWh) }\end{array}$ & $\begin{array}{l}\text { Particulate } \\
\text { Matter } \\
\text { Emissions } \\
\text { (t/TWh) }\end{array}$ & $\begin{array}{c}\text { Mercury } \\
\text { Emissions } \\
\text { (kg Hg/TWh) }\end{array}$ \\
\hline \multicolumn{9}{|c|}{ Options capable of meeting base load and peak load } \\
\hline $\begin{array}{l}\text { Hydropower } \\
\text { with } \\
\text { reservoir }\end{array}$ & $48-260$ & $2-48$ & $\begin{array}{c}2-152 \\
\text { projects } \\
\text { designed for } \\
\text { energy }\end{array}$ & $5-60$ & $3-42$ & & 5 & $\begin{array}{l}\quad 0,07 \\
\text { methylmercur } \\
y \text { in reservoirs }\end{array}$ \\
\hline Diesel & & $555-883$ & & $84-1550$ & $316+-12300$ & 1570 & $122-213+$ & \\
\hline
\end{tabular}

\section{Base load options with limited flexibility}

\begin{tabular}{|c|c|c|c|c|c|c|c|c|}
\hline $\begin{array}{l}\text { Hydropower } \\
\text { run-of-river }\end{array}$ & $30-267$ & $1-18$ & 0,1 & $1-25$ & $1-68$ & & $1-5$ & \\
\hline $\begin{array}{l}\text { Bituminous } \\
\text { coal:modern } \\
\text { plant }\end{array}$ & $7-20$ & $790-1182$ & 4 & $700-32321+$ & $700-5273+$ & $18-29$ & $30-663+$ & $1-360$ \\
\hline $\begin{array}{l}\text { Lignite: } \\
\text { old plant }\end{array}$ & & $1147-1272+$ & & $600-31941+$ & $704-4146+$ & & $100-618$ & $2-42$ \\
\hline $\begin{array}{l}\text { Heavy oil } \\
\text { without } \\
\text { scrubbing }\end{array}$ & 21 & $686-726+$ & & $8013-9595+$ & $1386+$ & $22+$ & & $2-13$ \\
\hline Nuclear & $5-107$ & $2-59$ & 0,5 & $3-50$ & $2-100$ & & 2 & \\
\hline $\begin{array}{l}\text { Natural gas } \\
\text { combined- } \\
\text { cycle turbines }\end{array}$ & 14 & $389-511$ & & $4-15000+$ & $13+-1500$ & $72-164$ & $1-10+$ & $0,3-1$ \\
\hline $\begin{array}{l}\text { Large fuel cell } \\
\text { (natural gas } \\
\text { to hydrogen } \\
\text { conversion) }\end{array}$ & & $290+-520+$ & & 6 & $0,3+-144$ & 65 & $2-6+$ & \\
\hline $\begin{array}{l}\text { Biomass: } \\
\text { energy } \\
\text { plantation }\end{array}$ & $3-5$ & $17-118$ & $533-2200$ & $26-160$ & $1110-2540$ & $89+$ & $190-212$ & $0,5-2$ \\
\hline $\begin{array}{l}\text { Biomass: } \\
\text { forestry } \\
\text { waste } \\
\text { combustion }\end{array}$ & 27 & $15-101$ & $0,9+$ & $12-140$ & $701-1950$ & & $217-320$ & \\
\hline \multicolumn{9}{|c|}{ Intermittent options that need a backup production (such as hydro with reservoir or oil-fired turbines) } \\
\hline Wind power & $5-39$ & $7-124$ & $24-117$ & $21-87$ & $14-50$ & & $5-35$ & \\
\hline $\begin{array}{l}\text { Solar } \\
\text { photovoltaic }\end{array}$ & $1-14$ & $13-731$ & $27-45$ & $24-490$ & $16-340$ & 70 & $12-190$ & \\
\hline
\end{tabular}

Source: IEA. May 2000. Hydropower and the Environment: Present Context and Guidelines for Future Action. Vol. II: Main Report, Ch.3: "Comparative Environmental Analysis of Power Generation Options". 
Table.2 . Comparison of GIS-generated estimates from the study with numbers of affected people documented in the literature.

\begin{tabular}{|c|c|c|c|}
\hline River name & $\begin{array}{l}\text { GIS-generated } \\
\text { estimate of number of } \\
\text { potentially affected } \\
\text { people }\end{array}$ & $\begin{array}{l}\text { Number of affected } \\
\text { people documented in } \\
\text { published studies }\end{array}$ & Reference \\
\hline Niger river inner delta, Mali & 367,000 & 300,000 fishers & Zwarts et al., 2005 \\
\hline $\begin{array}{l}\text { Senegal river valley, Mali, } \\
\text { Mauritania and Senegal }\end{array}$ & 231,000 & 364,132 farmers & Adams, 2000 \\
\hline $\begin{array}{l}\text { Sokoto river flood-plain, } \\
\text { Nigeria }\end{array}$ & 174,000 & $\begin{array}{l}50,000 \text { farmers; } \\
29,680 \text { fishers }\end{array}$ & $\begin{array}{l}\text { Hartenbach and } \\
\text { Schuol, } 2005\end{array}$ \\
\hline $\begin{array}{l}\text { Hadejia-Nguru wetlands, } \\
\text { Nigeria }\end{array}$ & 670,000 & $\begin{array}{l}1.5 \text { million farmers, } \\
\text { herders and fishers }\end{array}$ & $\begin{array}{l}\text { Nigerian } \\
\text { Conservation } \\
\text { Foundation, } 2006\end{array}$ \\
\hline Tana river, Kenya & 319,000 & $\begin{array}{l}1 \text { million farmers; } \\
54,400 \text { dependent } \\
\text { on fisheries }\end{array}$ & $\begin{array}{l}\text { Snoussi et al., } \\
\text { 2007; Emerton, } \\
1994\end{array}$ \\
\hline $\begin{array}{l}\text { Rufiji river flood-plain and } \\
\text { delta, Tanzania }\end{array}$ & 56,000 & $\begin{array}{l}16,093 \text { farming } \\
\text { households }\end{array}$ & Turpie, 2000 \\
\hline Sekong river, Lao PDR & 26,000 & 105,000 fishers & Lawrence, 2008 \\
\hline
\end{tabular}

Table.3. Number of 'potentially affected' rural people (in millions) living downstream of large reservoirs close to $(<10 \mathrm{~km})$ rivers, tabulated by degree of regulation and by river size.

\begin{tabular}{|c|c|c|c|c|c|c|c|c|c|}
\hline \multirow[t]{2}{*}{ Region } & \multirow[t]{2}{*}{ Total } & \multicolumn{4}{|c|}{$\begin{array}{l}\text { By degree of regulation } \\
\text { (cumulative upstream storage } \\
\text { capacity in } \% \text { of average annual flow) }\end{array}$} & \multicolumn{3}{|c|}{$\begin{array}{l}\text { By average river discharge } \\
\left(\mathrm{in} \mathrm{m}^{3} / \mathrm{s} \text { ) }\right.\end{array}$} & \multirow[b]{2}{*}{$>1000$} \\
\hline & & $10-25$ & $25-50$ & $50-100$ & $>100$ & $1-10$ & $10-100$ & $100-1000$ & \\
\hline Africa & 40.5 & 3.9 & 17.9 & 4.8 & 13.9 & 4.6 & 6.6 & 5.5 & 24.0 \\
\hline Asia & 399.6 & 217.4 & 57.5 & 58.7 & 65.9 & 38.8 & 84.5 & 74.4 & 201.9 \\
\hline Australia & 0.2 & 0.0 & 0.1 & 0.1 & 0.1 & 0.1 & 0.1 & 0.1 & 0.0 \\
\hline Europe & 17.0 & 5.1 & 2.7 & 2.5 & 6.8 & 2.4 & 5.2 & 5.4 & 3.9 \\
\hline North America ${ }^{a}$ & 8.7 & 2.3 & 2.0 & 1.9 & 2.5 & 2.1 & 3.1 & 2.4 & 1.0 \\
\hline South America ${ }^{b}$ & 5.7 & 1.0 & 0.9 & 2.0 & 1.7 & 1.0 & 2.0 & 1.8 & 0.8 \\
\hline Global total & $472.3^{\mathrm{c}}$ & 230.0 & 81.2 & 70.2 & 91.1 & 49.2 & 101.7 & 89.8 & 231.7 \\
\hline Deltas alone & 188.9 & 148.9 & 14.6 & 3.2 & 22.2 & 0.0 & 0.0 & 4.8 & 184.1 \\
\hline South-East Asia $^{\mathrm{d}}$ & 112.9 & 58.2 & 15.4 & 22.8 & 16.6 & 13.9 & 30.3 & 23.8 & 45.0 \\
\hline China & 143.1 & 55.0 & 15.9 & 30.2 & 42.0 & 26.7 & 44.2 & 22.0 & 50.1 \\
\hline India & 122.6 & 63.4 & 26.2 & 17.6 & 15.3 & 9.5 & 31.3 & 29.3 & 52.5 \\
\hline Bangladesh & 89.7 & 87.4 & 2.3 & 0.0 & 0.0 & 0.0 & 0.0 & 2.3 & 87.4 \\
\hline Nigeria & 21.7 & 1.5 & 15.7 & 1.9 & 2.6 & 2.0 & 3.0 & 1.5 & 15.2 \\
\hline Pakistan & 15.3 & 1.4 & 8.0 & 5.9 & 0.0 & 0.1 & 0.5 & 7.9 & 6.9 \\
\hline Thailand & 8.4 & 1.3 & 1.8 & 1.3 & 4.0 & 0.4 & 2.1 & 5.8 & 0.1 \\
\hline USA & 8.2 & 2.1 & 1.8 & 1.8 & 2.5 & 2.1 & 3.1 & 2.2 & 0.8 \\
\hline
\end{tabular}




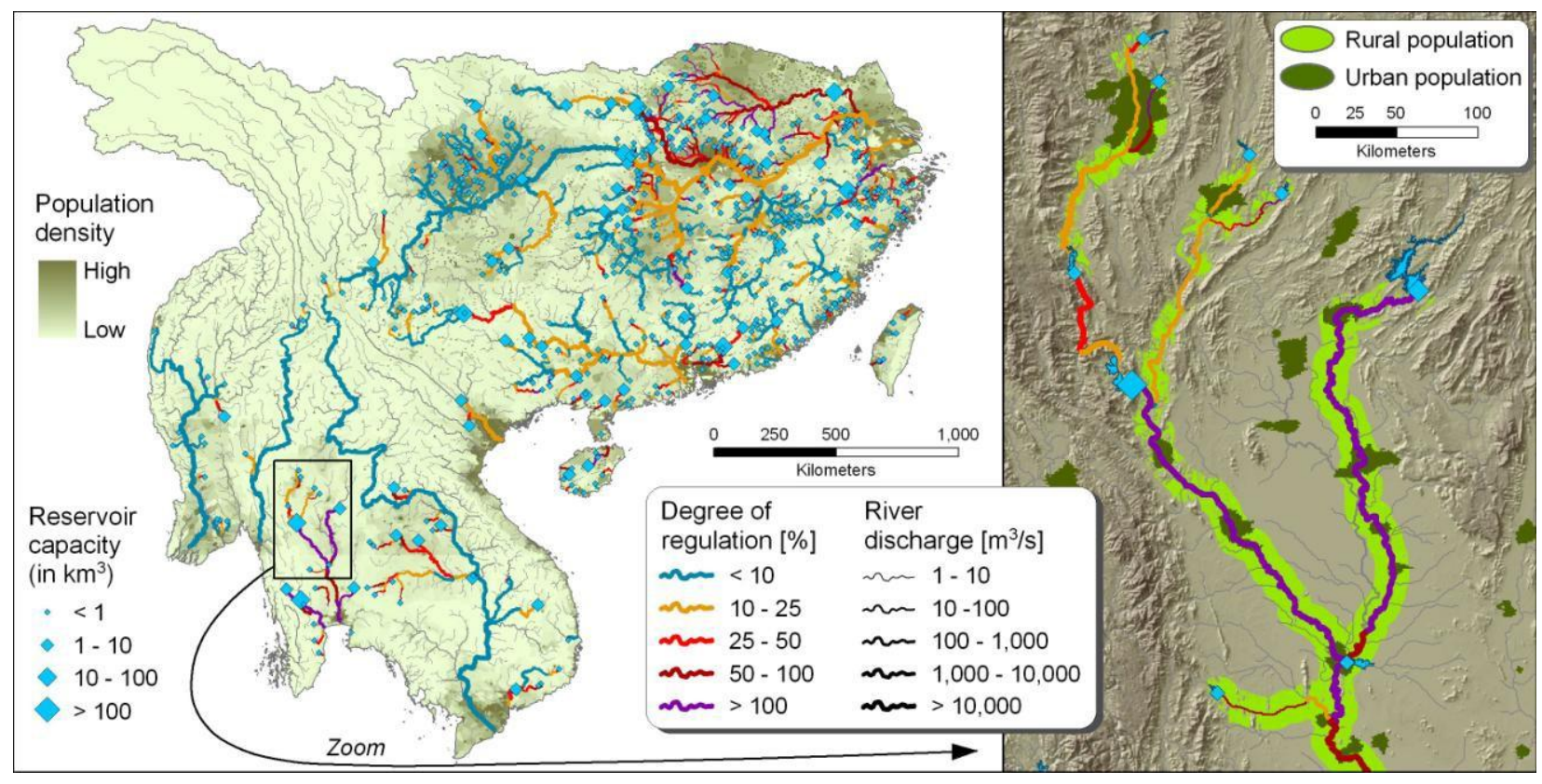

Figure.4. Illustration of the method used to estimate the size of downstream populations.

Left panel: Large reservoirs of Southeast Asia and their downstream impacted rivers; only those river reaches coloured orange, red, and purple are included in the assessment, blue ones (degree of regulation $<10 \%$ ) are excluded; grey rivers have no large dams upstream. Right panel: Zoom showing the $10-\mathrm{km}$ zones of influence around the affected rivers; areas steeper than 1 degree are excluded; only rural populations in these buffer zones are counted in the assessment (light green); urban populations (dark green) are excluded. 


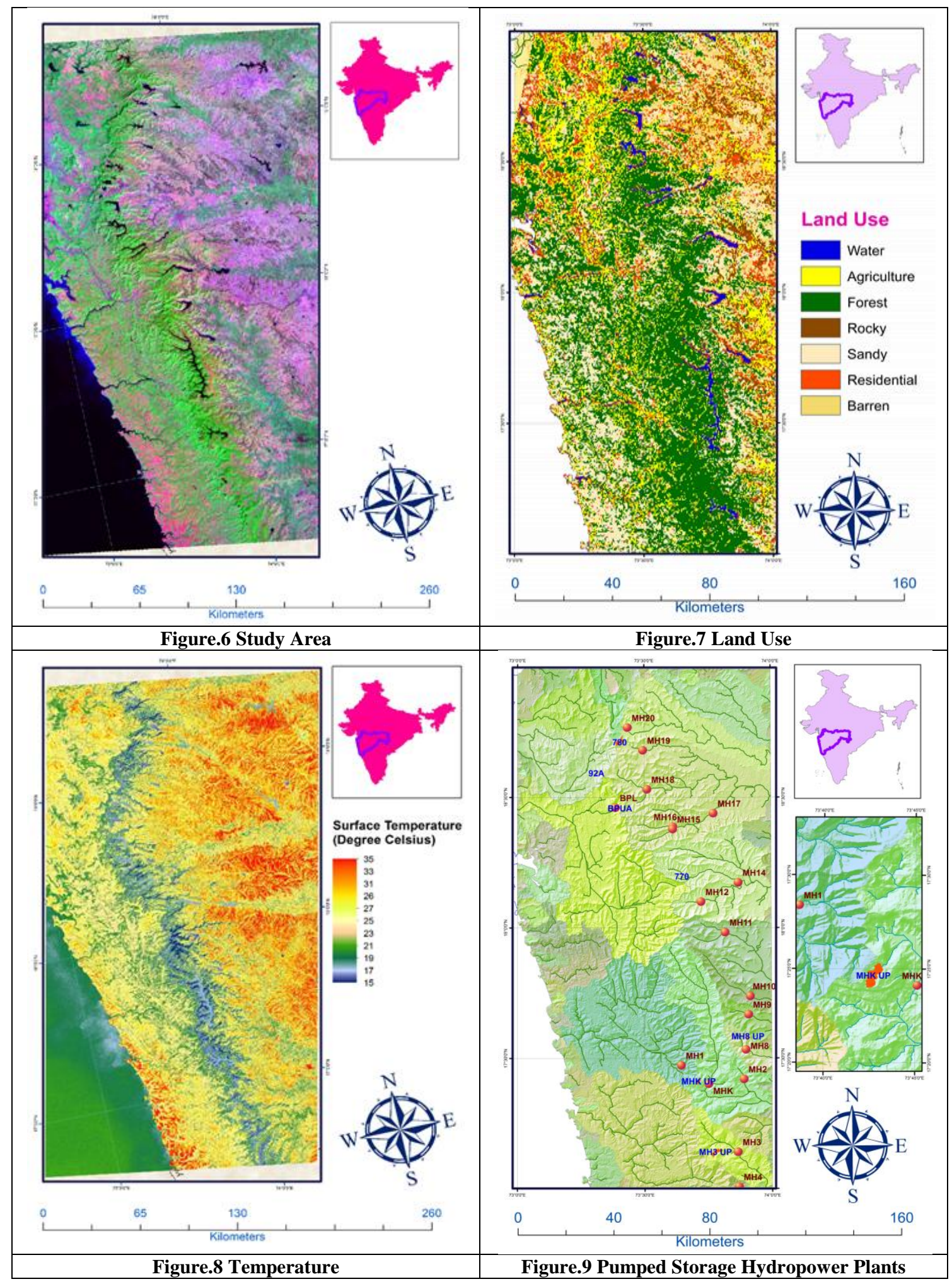




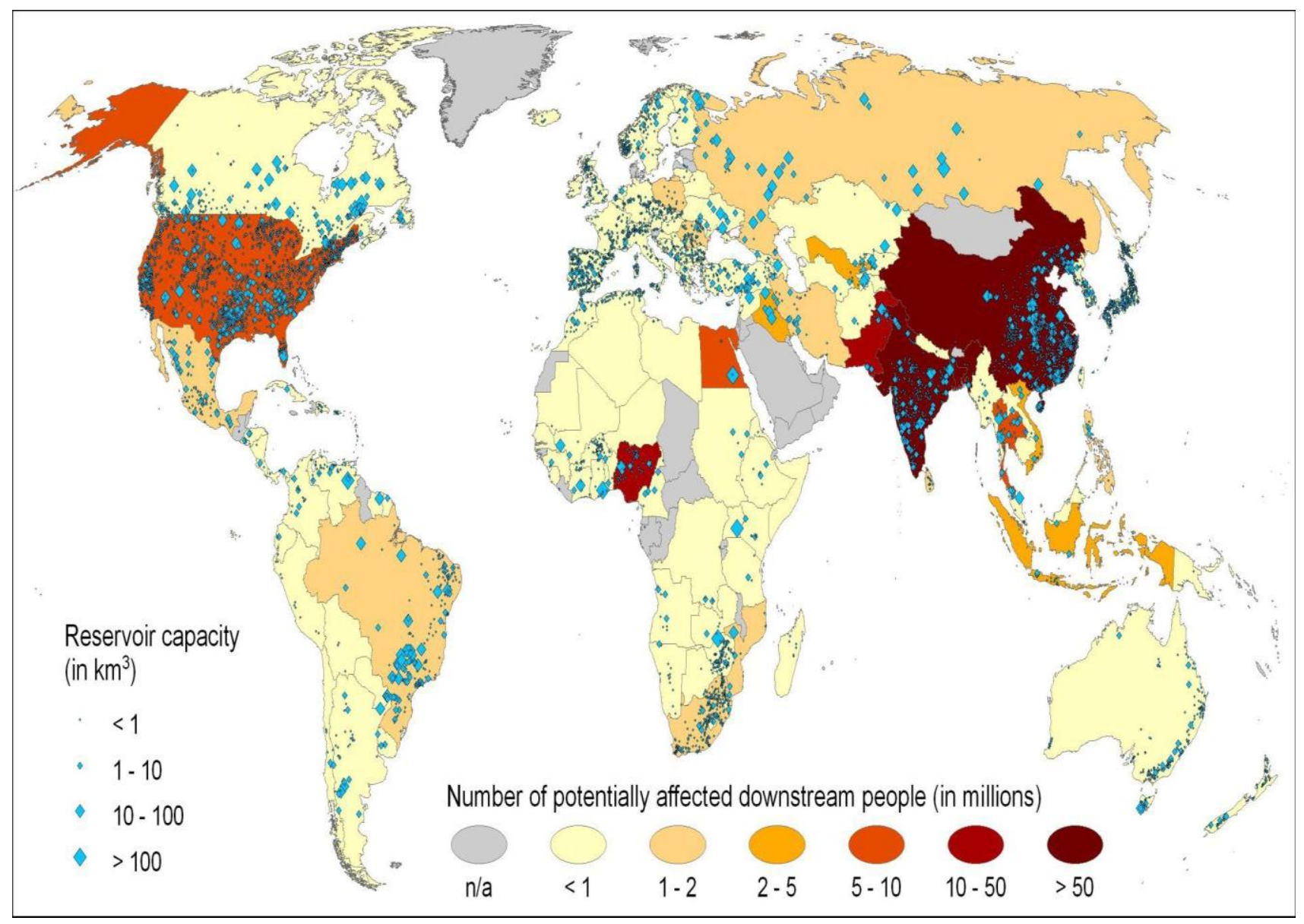

Figure.5. Distribution of 'potentially affected' rural people living downstream of large dams close to impacted rivers (numbers are totals per country). 